Laporan kasus

\title{
Polip endometrium pada sapi bunting tua
}

\section{Endometrial polyps in late gestation of cow}

\author{
Anang Yusuf ${ }^{1 *}$, Thomas Valentinus Widiyatno ${ }^{2 *}$, Abdul Samik ${ }^{3}$ \\ 1* Balai Budidaya dan Pembibitan Ternak Terpadu (BBPTT) Dinas Peternakan dan Kesehatan \\ Hewan Provinsi Jawa Tengah, ${ }^{2}$ Divisi Patologi Veteriner, ${ }^{3}$ Divisi Reproduksi Veteriner \\ Fakultas Kedokteran Hewan Universitas Airlangga \\ *Penulis koresponden, e-mail: dokterhewan_anang@yahoo.com, thvwidiyatno@fkh.unair.ac.id
}

Open access under CC BY - SA license, DOI: 10.20473/ovz.v10i1.2021.25-31

Received February 19 2021, Revised March 6 2021, Accepted March 142021

Published online April 12021

\begin{abstract}
The current report describes acute death in 8.5 months pregnant cow, without any preceding signs of illness. Postmortem examination showed the presence of bloat. Necropsy revealed no change in the viscera, but yellow and cloudy nodules were found on the endometrial wall, amniotic fluid mixed with blood, blood clots in the inner cervical canal, and pneumonia in the lungs. Meanwhile, the morphological of the fetus was normal, no physical defects were found. It could be concluded that the cow's sudden death was due to late pregnancy, causing high tension that triggers rupturing of the polyp blood vessels. The deep vein thrombosis due to late pregnancy causes pulmonary emboli and subsequent pneumonia.
\end{abstract}

Keywords: cow, emboli, endometrial polyp, late gestation, pneumonia, thrombus

\section{PENDAHULUAN}

Polip endometrium merupakan suatu pertumbuhan abnormal jaringan selaput lendir uterus yang digolongkan neoplasia jinak. Pada manusia polip endometrium biasanya terletak di bagian fundus, tersusun dari jaringan kelenjar, stroma dan memiliki banyak kapiler darah. Pada beberapa kasus polip endometrium bersifat prakanker atau kanker akibat mutasi gen (Nogueira et al., 2006). Pada wanita premenopause dan postmenopause, polip endometrium menjadi salah satu penyebab terjadinya perdarahan genital abnormal. Sedangkan pada wanita usia subur, polip endometrium dapat menyebabkan infertilitas (Lieng et al., 2010). Pathogenesis polip ini belum jelas, namun diduga berhubungan dengan respons terhadap stimulasi estrogen (Nijkang et al., 2019) yang berasal dari ekspresi berlebih dari aromatase endometrium (Pal et al., 2008) maupun yang berasal dari sistem sirkulasi (Tetikkurt et al., 2018).

Pada manusia polip endometrium dapat dideteksi dengan ultrasonografi vagina (sonohisterografi), atau histeroskopi (MayoClinic.com., 2006). Namun, pada sapi diagnosis tidak dilakukan lebih dini karena tidak adanya gejala, kecuai terjadi kematian. Pada manusia prevalensi polip endometrium secara umum adalah $24 \%$, lebih tinggi pada wanita pascamenopause dibandingkan dengan wanita premenopause. Insiden temuan ganas atau pra-ganas pada polip endometrium berkisar antara $0,5-4,8 \%$ pada populasi umum dan dari 2-10\% pada wanita menopause (Lissak, 2013). Pada hewan, polip endometrium pernah dilaporkan terjadi pada kuda (Yamini et al., 1994), kucing (Madarame et al., 2003) dan anjing (Gumber et al., 2010), namun pada sapi 
sampai saat ini belum pernah dilaporkan. Tujuan studi ini adalam untuk membahas kematian sapi bunting tua sebagai komplikasi polip endometrium.

\section{MATERI DAN METODE}

Seekor sapi Peranakan Ongole (PO) terdiagnosa polip endometrium pada tanggal 21 Desember 2020 di desa Sumberrejo, kecamatan Kaliwungu, kabupaten Kendal. Sapi berumur empat tahun, bunting kedua, umur kebuntingan 8,5 bulan. Hasil anamnesis dari anak kandang kondisi sapi pada tanggal 20 Desember 2020 sore masih makan dengan normal ditandai dengan habisnya pakan yang ada ditempat pakan. Pagi pukul 06.00 WIB tanggal 21 Desember 2020 sapi ditemukan sudah dalam keadaan mati. Diagnosa dilakukan berdasarkan pemeriksaan fisik dan nekropsi (bedah bangkai).

Pencatatan data populasi dilakukan sebagai bahan perbandingan kondisi pemeliharaan antara sapi yang mati dengan sapi-sapi lainnya, sedangkan pendataan pakan dilakukan sebagai bahan analisis kemungkinan kematian karena faktor keracunan. Peternakan dimana kematian sapi ini terjadi memiliki jumlah ternak terdiri atas 312 ekor sapi Peranakan Ongole yang terdiri dari 137 ekor betina dewasa, 26 betina muda, 149 pedet. Pakan untuk sapi indukan berupa rumput gajah (Pennisetum purpureum) $10 \%$ berat badan/hari. Konsentrat pabrikan (Nufeed, www.nufeed.co.id) $1 \%$ berat badan /hari. Rumput gajah memiliki kandungan nutrien berupa bahan kering 20,29\%, protein kasar 6,26\%, lemak 2,06\%, serat kasar 32,60\%, abu $9,12 \%$, bahan ekstrak tanpa nitrogen (BETN) 41,82\%, kalsium 0,46\%, dan fosfor 0,37\% (Rustiyana et al., 2016). Kandungan gizi konsentrat terdiri atas protein (minimum) $18 \%$, lemak (maksimum) 7\%, serat kasar (maksimum) 7\%, abu (maksimum) 10\%, kadar air (maksimum) $12 \%$, total digestible nutrien $70 \%$, kalsium $0,4-0,6 \%$, dan fosfor $0,6-0,8 \%$. (https://www.nufeed.co.id/index.php/products).

\section{HASIL}

Pemeriksaan postmortem menunjukkan akumulasi gas pada saluran digesti sehingga abdomen bagian kiri menggembung sangat besar dan dipastikan tes suara timpani. Terdapat leleran cairan amnion bercampur darah keluar dari vulva (Gambar 1).

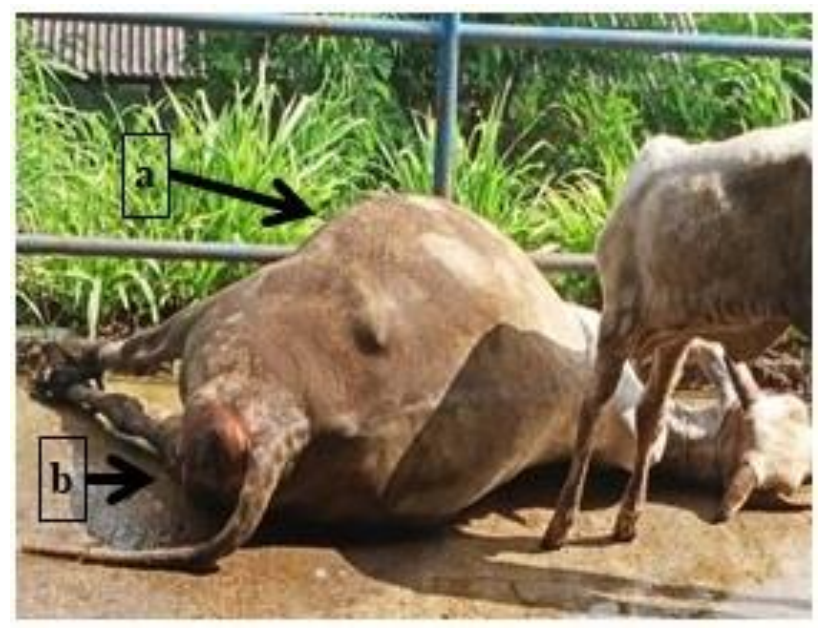

Gambar 1 Kondisi sapi sebelum nekropsi, menunjukkan akumulasi gas pada abdomen sisi kiri (a) dan leleran cairan amnion bercampur darah keluar dari vulva (b).

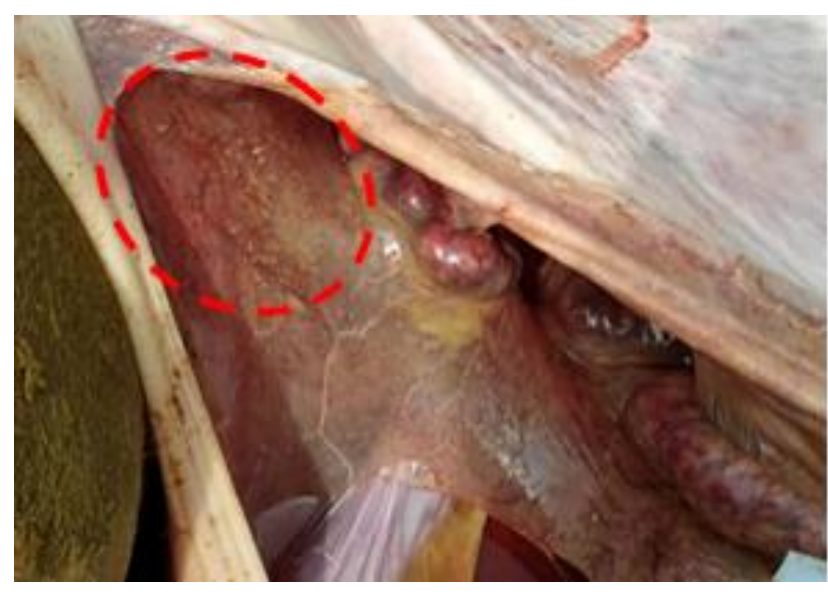

Gambar 2 Polip sesil berbentuk nodul kuning dan keruh berdiameter $0,5-1 \mathrm{~cm}$ pada dinding endometrium (lingkaran merah)

Hasil nekropsi menunjukkan kondisi organ secara umum tidak ada perubahan, namun dijumpai nodul kuning dan keruh pada dinding endometrium. Polip dengan diameter $0,5-1 \mathrm{~cm}$ terdapat sekitar 20 buah dan diameter kurang dari $0,5 \mathrm{~cm}$ lebih banyak jumlahnya (Gambar 2), cairan amnion bercampur darah (Gambar 3), bekuan darah berwarna hitam pada lumen servik (Gambar 4), terjadi pneumonia (Gambar 5), sedangkan kondisi fisik fetus normal (Gambar 6). 


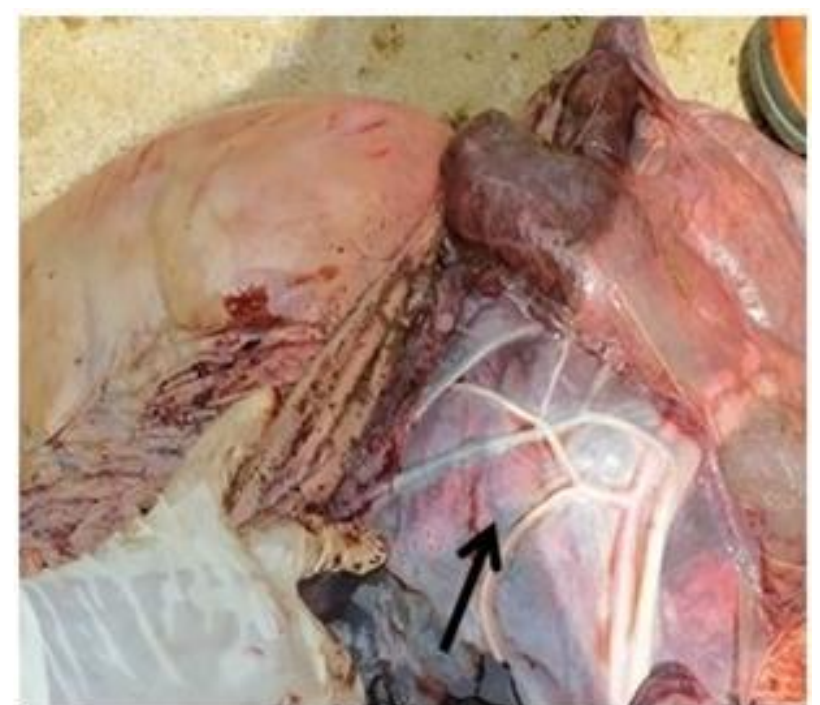

Gambar 3 Cairan amnion bercampur darah

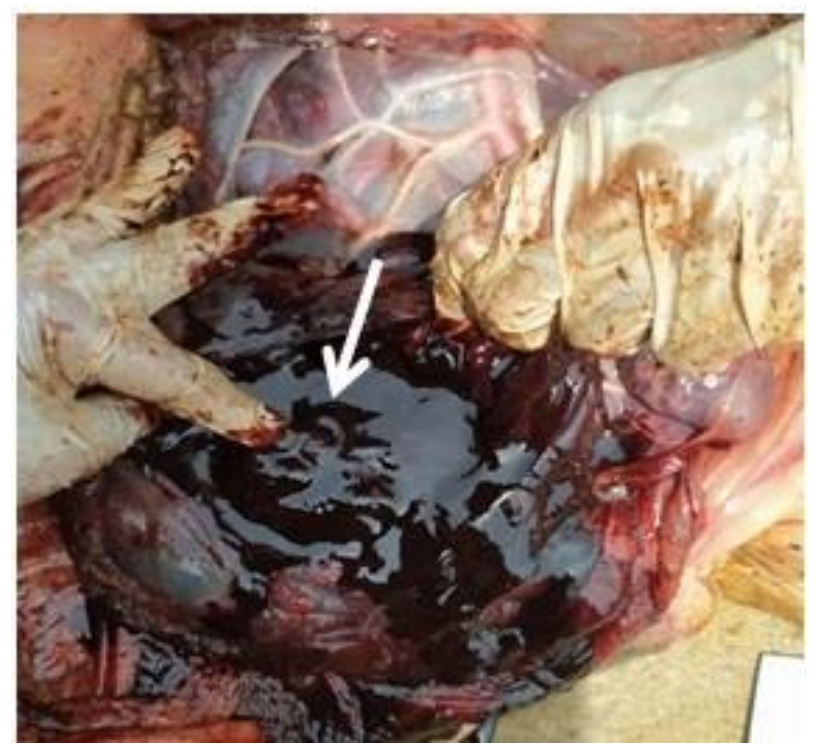

Gambar 4 Bekuan darah pada lumen servik

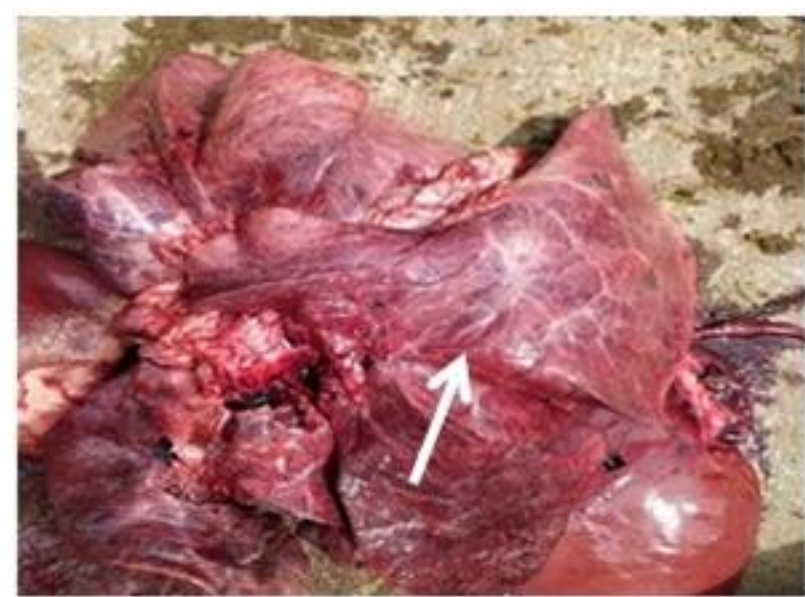

Gambar 5 Pneumonia pada paru-paru

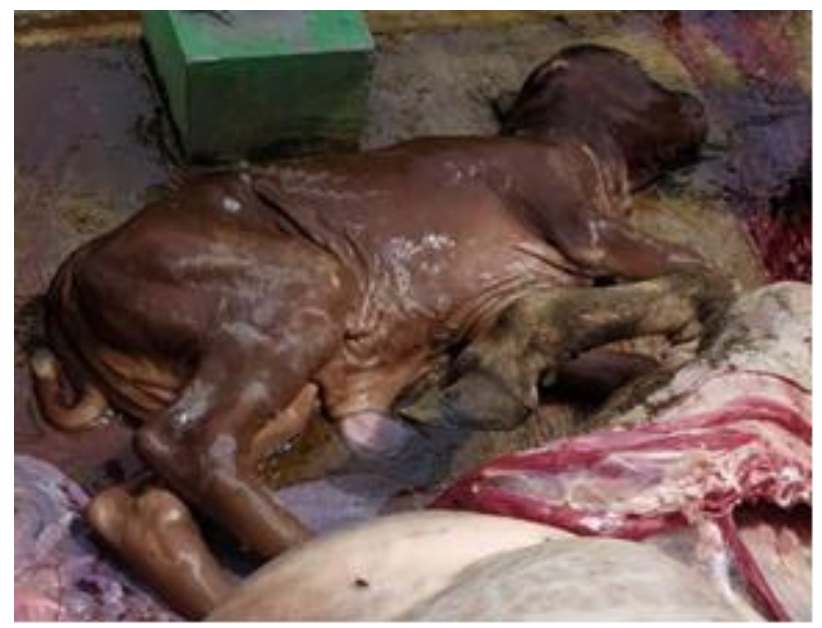

Gambar 6 Kondisi fisik fetus normal

\section{DISKUSI}

Uterus sapi bunting terletak di sisi kanan abdomen, karena sisi kiri ditempati rumen. Mesometrium atau ligamenta lata uteri tertarik dan menjadi tegang oleh beratnya fetus dan uterus bunting. Pada awal kebuntingan lendir serviks berubah menjadi kental (plug) sehingga menutup lumen servik. Perubahan sifat lendir serviks menjadi kental dibawah pengaruh hormon progesteron. Pada kebuntingan trimester pertama dan kedua progesteron menyebabkan canalis cervicalis lebih tertutup, kripta endoservikal bertambah jumlahnya dan menghasilkan lendir atau mukus yang sangat kental menyumbat canalis cervicalis. Plug tersebut akan mencair segera sebelum partus dan dikeluarkan dalam bentuk tali-tali mucus (Jainudeen dan Hafez, 2016). Uterus semakin membesar secara progresif sesuai dengan bertambahnya ukuran tubuh fetus. Panjang fetus pada akhir kebuntingan membentang diantara diafragma dan pelvis. Hormon progesteron menyebabkan peningkatan vaskularisasi, pertumbuhan dan perkembangan endometrium untuk menghasilkan uterine milk sebagai makanan embrio, serta infiltrasi leukosit ke dalam lumen uterus bertujuan sebagai pertahanan pertama dari induk untuk melindungi embrio dari benda asing. Embrio dibawah pengaruh hormon progesteron juga memproduksi protein spesifik untuk melawan sel lekosit dari induk sehingga embrio mampu bertahan hidup (Noakes et al., 2008). 


\section{Akumulasi gas dalam rumen}

Akumulasi gas pada saluran digesti (timpani) diduga terjadi setelah kematian. Setelah sapi mati maka tidak ada aktivitas rumen, sedangkan mikroba tetap bermetabolisme menghasilkan timbunan gas yang tidak dapat dikeluarkan dari tubuh sapi. Pakan dan konsentrat pada kondisi tubuh tertentu dapat menyebabkan timpani (Yanuartono et al., 2018). Pakan hijauan rumput gajah dan konsentrat Nufeed telah dipergunakan dalam dalam jangka panjang di peternakan ini dan tidak menimbulkan masalah pada kesehatan sapi. Terjadinya akumulasi gas pada rumen dari kasus penyakit ini bukan disebabkan oleh pakan namun oleh pengaruh mikroba rumen setelah kematian masih terjadi proses fermentasi sehingga menghasilkan gas.

\section{Polip}

Polip endometrium dapat berupa polip tunggal atau majemuk, berbentuk bulat atau oval dan berdiameter antara beberapa milimeter dan beberapa sentimeter (Bajo Arenas et al, 2005). Warna polip endometrium biasanya merah atau coklat atau kekuningan, pada polip yang besar tampak berwarna merah gelap (DeCherney et al., 2003). Polip melekat pada endometrium dengan tangkai (polip bertangkai atau pedunculated polyp) atau berupa bidang datar (sesille polyp) (Gregoriou et al., 2009). Bentuk polip endometrium pada sapi ini berupa nodul kuning dan keruh berdiameter antara 0,5$1 \mathrm{~cm}$ pada dinding endometrium (Gambar 2) sehingga digolongkan sesille polyp (Nijkang et al., 2019).

\section{Cairan amnion bercampur darah}

Secara umum pada sapi bunting 8-9 bulan jumlah cairan fetus berkisar 12-20 liter, dengan panjang fetus $60-85 \mathrm{~cm}$, berat fetus $36-38 \mathrm{~kg}$, diameter plasentom $8-12 \mathrm{~cm}$ (Buczinski et al, 2011). Pada kebuntingan tua, ukuran dan berat fetus serta adanya polip akan berisiko robeknya plasenta (abruptio placentae). Hal ini sering dikaitkan dengan perdarahan ante partum (Wasnik dan Naiknaware, 2015).

Polip endometrium menyebabkan gangguan imunitas seluler lokal yang konsisten dengan aktivitas mast cells yang berlebihan. Sel
$\mathrm{T}$ regulator akan direkrut ke polip endometrium dalam upaya untuk menekan proses inflamasi karena adanya mast cells yang sangat meningkat. Gangguan imunologi ini menjadi penyebab rapuhnya pembuluh darah pada polip yang kemudian menimbulkan perdarahan abnormal (El-Hamarneh et al., 2013). Polip endometrium sering tidak menimbulkan gejala (Sternberg, 2004), pendarahan dapat terjadi dari pecahnya pembuluh darah polip (DeCherney et al., 2003).

Pada stroma polip endometrium terdapat vaskularisasi dan beberapa lapis otot polos (Mutter et al., 2009). Pada kebuntingan 8-9 bulan kadar progesterone mulai berkurang sehingga menurunkan nilai ambang rangsang dan estrogen mulai naik, sehingga otot polos mulai meningkatkan tonus dan berkontraksi (Schuler et al., 2018). Kontraksi pada otot polos yang ada pada polip dapat memicu pecahnya pembuluh darah.

\section{Akumulasi darah pada canalis cervicalis}

Pada kebuntingan umur 8,5 bulan, ukuran dan metabolism fetus mendekati maksimum, sehingga fetus mulai mengalami stress karena keterbatasan ruangan dan pasokan nutrisi dari induknya. Fetus mengalami hipoksia, hiperkapnia, hipertensi, kekurangan kadar glukosa darah yang memicu rangsangan kepada hipotalamus agar hipofisa mensekresikan adrenocorticotropic hormone (ACTH). Selanjutnya ACTH akan merangsang korteks adrenal untuk menghasilkan fetal adrenal kortikosteroid yang memicu plasenta menghasilkan estrogen feto-plasental dan mempengaruhi kotiledon untuk mengeluarkan prostaglandin F2 $\alpha$. Hormon PGF2 $\alpha$ akan meregresi korpus luetum, sehingga kadar progesteron menurun yang mengakibatkan batas ambang kontraksi myometrium turun. Hormon PGF2 $\alpha$ secara langsung dapat merelaksasi serviks, ligamenta pelvis, dan perineum, atau secara tidak langsung dengan cara merangsang disekresikannya relaksin (Noakes et al., 2008). Kadar estrogen yang meningkat dan kadar progesteron yang menurun menyebabkan mencairnya lendir serviks, sehingga sumbat pada lumen serviks menjadi terbuka (Bernardi et al., 2016; Jainudeen dan 
Hafez, 2016). Kondisi relaksasi canalis servikalis dan mencairnya lendir serviks menyebabkan darah yang berasal dari pecahnya vaskuler pada polip masuk kedalam canalis servikalis.

\section{Penumonia}

Pada hewan yang sedang bunting tua serta jarang sekali beraktifitas fisik, maka akan mudah terjadi gangguan peredaran darah di sekitar wilayah pelvis dan juga ekstremitas belakang. Pada kasus ini perdarahan dapat diakibatkan oleh pecahnya pembuluh darah polip (DeCherney et al., 2003). Bila ini berlangsung cukup lama, terbentuknya bekuan darah ante mortem (trombus) akan besar kemungkinan terjadi. Inilah yang dikenal dengan sebutan Deep Vein Thrombosis (DVT), trombosis yang terjadi pada pembuluh balik besar yang terletak di bagian dalam (Stone et al., 2017). Kongesti atau genangan darah akibat kebuntingan (venous stasis), seringkali bersamaan dengan terjadinya jejas vaskular dan hiperkoagulopati, yang kemungkinan juga terjadi pada hewan yang bersangkutan, sehingga trombosis juga akan lebih mudah terjadi (Patel dan Surowiec, 2020).

Trombus pada pembuluh balik, apabila sudah membentuk massa yang cukup besar, sebagian dari masa tersebut bisa terlepas dan menjadi emboli padat yang ikut aliran pembuluh balik yang kemudian akan sampai ke jantung, masuk melalui atrium kanan. Melalui katup tricuspidalis embolus darah itu masuk ke bilik kanan dan akan dipompakan ke paru-paru melalui arteri pulmonalis yang kemudian bercabang menuju paru-paru kiri dan kanan (Tarbox dan Swaroop, 2013). Emboli yang berukuran kecil berhasil melalui arteri pulmonalis, namun pada akhirnya akan tertahan pada pembuluh-pembuluh darah paru-paru yang berdiameter lebih kecil, yang berakibat rupturnya endotel, karena terjadi hipertensi pulmoner. Kejadian fatal bisa terjadi akibat emboli pulmoner akut (Howard, 2019), atau pada kasus lain bisa terjadi akibat gagal jantung kanan (right-sided heart failure) (Elliot et al., 2005) yang menyebabkan kematian induk bunting tua.

\section{Kondisi anatomis fetus normal}

Polip yang berkembang di dekat tuba falopi, dapat menyebabkan kesulitan untuk bunting (Rubin dan Strayer, 2007). Sedangkan polip yang tumbuh jauh dari tuba falopii tidak menghalangi terjadinya kebuntingan. Namun, apabila fertilisasi, implantasi dan plasentasi telah terjadi tanpa terganggu oleh polip endometrium, maka fetus akan berkembang normal (Al Chami dan Saridogan, 2017).

\section{KESIMPULAN}

Berdasarkan pembahasan tersebut dapat disimpulkan bahwa polip endometrium pada sapi bunting tua cenderung akan mudah mengalami perdarahan karena pecahnya pembuluh kapiler polip. Bekuan darah yang terjadi sekaligus bersamaan dengan masa fetus yang berat akan menghasilkan thrombus. Sequela yang dihasilkan trombus bisa kembali melalui pembuluh balik ke jantung dan paruparu dan bisa menyebabkan gagal jantung atau emboli pulmoner yang menyebabkan pneumonia dan kematian mendadak.

Kesimpulan tersebut lebih akurat apabila disertai pemeriksaan histopatologis. Disarankan apabila menemukan kasus yang memerlukan kepastian diagnosis, hendaknya dilakukan pengambilan sampel pada organ tubuh yang secara morfologis mengalami perubahan postmortem.

\section{DAFTAR PUSTAKA}

Al Chami A, Saridogan E. 2017. Endometrial Polyps and Subfertility. J Obstet Gynaecol India. 67: 9-14.

Bajo Arenas, José M, Kurjak A. 2005. Donald School Textbook of Transvaginal Sonography. Taylor \& Francis. 502.

Bernardi S, Rinaudo A, Marini P. 2016. Cervical mukus characteristics and hormonal status at insemination of Holstein cows. IJVR 17: 45-9.

Buczinski S, Fecteau G, Lefebvre RC, Smith LC. 2011. Assessment of fetal well-being in cattle by ultrasonography in normal, high-risk, and cloned pregnancies. Can Vet J. 52: 136-41. 
DeCherney, Alan H, Nathan L, 2003. Current obstetric \& gynecologic diagnosis \& treatment. McGraw-Hill Professional. 703.

El-Hamarneh T, Hey-Cunningham AJ, Berbic M, Al-Jefout M, Fraser IS, Black K. 2013. Cellular immune environment in endometrial polyps. Fertility and Sterility 100: 1364-72.

Elliot CG, Goldhaber SZ, Jensen RL. 2005. Delays in diagnosis of deep vein thrombosis and pulmonary embolism. Chest 128: 3372-6.

Gregoriou O, Konidaris S, Vrachnis N, Bakalianou K, Salakos N, Papadias K, Kondi-Pafiti A, Creatsas G. 2009. Clinical parameters linked with malignancy in endometrial polyps. Climacteric 12:454.

Gumber S, Springer N, Wakamatsu N. 2010. Uterine endometrial polyp with severe hemorrhage and cystic endometrial hyperplasia-pyometra complex in a dog. J Vet Diagn Invest. 22: 455-8.

Howard L. 2019. Acute pulmonary embolism. Clinical Medicine 19: 243-7.

Jainudeen MR, Hafez ESE. 2016. Gestation, prenatal physiology, and parturition, In: Reproduction in Farm Animals. Hafez and Hafez (Ed) 7th ed. Lippincott William \& Wilkins. A Wolter Kluwer Company. 14051.

Lieng M, Istre O, Qvigstad E. 2010. Treatment of endometrial polyps: a systematic review. Acta Obstet Gynecol Scand. 89: 992.

Lissak A. 2013. Incidence of Malignant and Premalignant Endometrial Polyp in Asymptomatic and Symptomatic Postmenopausal Women. https:// clinicaltrials.gov/ct2/show/NCT01203176

Madarame H, Sato K, Tsuchiya R. 2003. Endometrial polyps in a cat. $\mathrm{J}$ Toxicol Pathol 16:109-12.

MayoClinic.com. 2006. Uterine polyps. https://www.mayoclinic.org/diseasesconditions/uterine-polyps/symptomscauses/syc-20378709 (Accessed February 18 2021)

Mutter GL, Nucci, MR, Robboy SJ. 2009. Endometritis, metaplasias, polyps, and miscellaneous changes. In: Robboy's Pathology of the Female Reproductie Tract, 2nd ed., Robboy SJ, Mutter GL, Prat J, et al (Eds), Churchill Livingston Elsevier, Oxford. 343.

Nijkang NP, Anderson L, Markham R, Manconi F. 2019. Endometrial polyps: Pathogenesis, sequelae and treatment. SAGE Open Med. 7:2050312119848247.

https://doi.org/10.1177/2050312119848247

Noakes D, Parkinson T, England G, Arthur G. 2008. Arthur's Veterinary Reproduction and Obstetrics 8th Edition. Saunders Ltd. 157-9.

Nogueira AA, Sant'Ana de Almeida EC, Poli Neto OB, Zambelli Ramalho LN, Rosa e Silva JC, Candido dos Reis FJ. 2006. Immunohistochemical expression of p63 in endometrial polyps: evidence that a basal cell immunophenotype is maintained. Menopause 13: 826.

Pal L, Niklaus AL, Kim M, Pollack S, Santoro N. 2008. Heterogeneity in endometrial expression of aromatase in polyp-bearing uteri. Hum Reprod. 23: 80.

Patel SK, Surowiec SM. 2020. Venous Insufficiency. [Updated 2020 Nov 20]. In: StatPearls [Internet]. Treasure Island (FL): StatPearls Publishing; 2020 Jan-. Available from: https:// www.ncbi.nlm.nih.gov/books/NBK430975/ Rubin R, Strayer DS. 2007. Rubin's Pathology: Clinicopathologic Foundations of Medicine. Lippincott Williams \& Wilkins. 806.

Rustiyana E, Liman L, Fathul F. 2016. Pengaruh substitusi rumput gajah (Pennisetum purpureum) dengan pelepah daun sawit terhadap kecernaan protein kasar dan kecernaan serat kasar pada kambing. Jurnal Ilmiah Peternakan Terpadu 4: 161-5.

Schuler G, Fürbass R, Klisch K. 2018. Placental contribution to the endocrinology of gestation and parturition. Anim Reprod. 15: 822-42.

Stone J, Hangge P, Albadawi H, Wallace A, Shamoun F, Knuttien MG, Naidu S, Oklu R. 2017. Deep vein thrombosis: pathogenesis, diagnosis, and medical management. Cardiovasc Diagn Ther. 7: S276-S284. 
Tarbox AK, Swaroop M. 2013. Pulmonary embolism. Int J Crit Illn Inj Sci. 3: 69-72.

Tetikkurt S, Çelik E, Taş H, Cay T, Işik S, Usta AT. 2018. Coexistence of adenomyosis, adenocarcinoma, endometrial and myometrial lesions in resected uterine specimens. Molecular and Clinical Oncology 9: 231-7.

Wasnik SK, Naiknaware SV. 2015. Antepartum haemorrhage: causes \& its effects on mother and child: an evaluation. Obstet Gynecol Int J. 3: 255-8.
Yamini B, Borg L. 1994. Endometrial polyps and endometritis in a thoroughbred filly. $\mathrm{J}$ Vet Diagn Invest 6: 496-8.

Yanuartono SI, Nururrozi A, Purnamaningsih H, Raharjo S. 2018. Peran pakan pada kejadian kembung rumen. Jurnal Ilmu-Ilmu Peternakan 28: 141-57. 